\title{
Clive R. Sneddon, On the creation of the "Old French
} Bible"

\section{G. Matteo Roccati}

\section{CpenEdition}

1 Journals

\section{Édition électronique}

URL : http://journals.openedition.org/studifrancesi/34281

DOI : 10.4000/studifrancesi.34281

ISSN : 2427-5856

Éditeur

Rosenberg \& Sellier

\section{Édition imprimée}

Date de publication : 1 novembre 2005

Pagination : 389

ISSN : 0039-2944

\section{Référence électronique}

G. Matteo Roccati, «Clive R. Sneddon, On the creation of the "Old French Bible" », Studi Francesi [En ligne], 146 (XLIX | II) | 2005, mis en ligne le 30 novembre 2015, consulté le 19 avril 2021. URL : http:// journals.openedition.org/studifrancesi/34281; DOI : https://doi.org/10.4000/studifrancesi.34281

Ce document a été généré automatiquement le 19 avril 2021.

\section{(c) $(1) \&$}

Studi Francesi è distribuita con Licenza Creative Commons Attribuzione - Non commerciale - Non opere derivate 4.0 Internazionale. 


\section{Clive R. Sneddon, On the creation of the "Old French Bible"}

\section{G. Matteo Roccati}

\section{RÉFÉRENCE}

CLIVE R. SNEDDON, On the creation of the "Old French Bible", "Nottingham Medieval Studies", XLVI, 2002, pp. 25-44.

1 Par l'étude des manuscrits et des caractères de la traduction (prologue, gloses), l'article essaye de cerner le contexte dans lequel la Bible du XIII ${ }^{\mathrm{e}}$ siècle (selon la terminologie de $\mathrm{S}$. Berger) a vu le jour. Il conclut en formulant l'hypothèse que le texte a été réalisé par des dominicains à Orléans vers la fin des années 1240 sous l'impulsion de Louis IX et Blanche de Castille; il a ensuite été révisé à l'adresse d'un public laïc - quatre états sont attestés entre 1260 et 1300 . 